\title{
VALIDITAS BAHAN AJAR MICROSOFT POWER POINT - GOOGLE FORM (MC.POINT-GG.FORM) UNTUK PEMBELAJARAN IPA DI SMP NEGERI 1 DRINGU
}

\author{
${ }^{1}$ Retno Irawati \\ ${ }^{1}$ SMP Negeri 1 Dringu Kabupaten Probolinggo \\ J1. Yos Sudarso No. 129 Dringu Probolinggo \\ email: ira.retno99@gmail.com
}

\begin{abstract}
This research purpose was to produce Microsoft Power Point teaching materials - Google Form (MC.Point-gg.Form) for valid science learning, this teaching material is one of using handphone for the learning process. This teaching material contains static electricity material. This study uses the 4D method (1) define, 2) design, 3) develop and 4) disseminate. This research was applied on one class, IXF which consisted of 32 students. In the teaching material consists of tutorials using MC.Point-gg.Form, learning objectives, material, assessment of pre-test and post-test learning outcomes. The results of the study is in the form of data validation scores for Microsoft Power Point Teaching Materials - Google Form (MC.Point-gg.Form). Evaluation of the validity of teaching materials by experts obtain the following percentage ratings: (1) validation of the material $87,26 \%$ with a very valid category, (2) $88,33 \%$ programming validation with a very valid category, (3) display validation $90,03 \%$ with a very valid category. (4) validation of user responses (teachers) $82 \%$ with a very valid category so that Microsoft Power Point and Google Form teaching materials (Mc. Point-gg.form) can be used.
\end{abstract}

Keywords: interactive demonstration, learning outcomes, natural science

\section{PENDAHULUAN}

Pembelajaran pada abad 21 harus memiliki kecakapan yang akan menjadi fokus perhatian pemerhati dan praktisi pendidikan. Menurut The North Central Regional Education Laboratory (NCREL) dan The Metiri Grup (2003) dalam (Trisdiono, 2013) untuk mengidentifikasi kerangka kerja dibagi menjadi empat kategori antara lain kemahiran era digital, berpikir inventif (menemukan ide baru dan original), komunikasi yang efektif, dan produktivitas yang tinggi.

ATCS (assesment and teaching for 21st century skills) berpendapat ada empat kategori dalam kecakapan abad 21 yaitu cara berpikir, cara bekerja, alat kerja dan kecakapan hidup. Cara berpikir meliputi kreatif, berpikir kritis, pemecahan masalah, pengambilan keputusan dan belajar. Cara kerja bagian dari komunikasi dan kolaborasi. Alat yang digunakan bekerja mencakup teknologi informasi dan komunikasi dan literasi informasi. Sedangkan kecakapan hidup mencakup kewarganegaraan, kehidupan dan karir, dan tanggung jawab pribadi dan sosial.
Kurikulum 2013 dirancang dan saat ini diterapkan sebagai langkah awal untuk mengantisiasi perkembangan di masa mendatang. Inti dari kurikulum 2013 menitik beratkan pada tujuan untuk mendorong peserta didik melakukan observasi, bertanya, menalar dan mengkomunikasikan data/materi yang telah mereka dapatkan dalam pembelajaran (Anwar, 2014). Kurikulum 2013 menitiberatkan pada 4 kompetensi inti yaitu sikap spiritual, sosial, pengetahuan dan keterampilan. melalui pendekatan tersebut peserta didik diharapkan dapat meningkatkan kompetensinya yang mengalami perubahan terkait dengan standar kompetensi lulusan, standar proses, standar isi dan standar penilaian. Kurikulum 2013 menginginkan menjadikan peserta didik yang kreatif dan berkarakter siap untuk menghadapi tantangan abad 21. Dalam kegiatan pembelajaran agar berjalan efektif dibutuhkan media pembelajaran yang berupa bahan ajar yang tidak hanya menekankan penguasaan konsep saja tetapi juga memberikan penekanan pada kemampuan siswa untuk berpikir kritis, 
menganalisa permasalahan, dan mampu menyampaikan pendapat dari setiap materi yang berkaitan dengan situasi yang nyata (Virani et al., 2018).

Bahan ajar yang efektif dan interaktif dapat menarik perhatian siswa sehingga lebih memotivasi dalam belajar. Menurut Lestari (2013), bahan ajar adalah seperangkat materi pelajaran yang disusun berdasarkan kurikulum untuk mencapai standar kompetensi dan kompetensi dasar. Bahan ajar dikelompokan menjadi tiga kelompok; bahan ajar cetak, non cetak, dan display. Bahan ajar cetak ditampilkan menggunakan kertas. Bahan ajar non cetak ditampilkan menggunakan mediamedia elektronik (laptop, komputer, LCD, internet, handphone), sedangkan bahan ajar display ditampilkan berupa poster, foto, gambar, dan peta.

Bahan ajar bertujuan untuk mempermudah proses pembelajaran, selain itu bahan ajar juga digunakan untuk mencapai hasil belajar yang baik dan sesuai dengan yang diharapkan. Bahan ajar dapat digunakan oleh siswa sebagai acuan dalam melakukan belajar mandiri dan mengembangkan potensi dan membangun karakter siswa melalui tahapan kerja ilmiah dan nilai-nilai karakter yang disampaikan melalui bahan ajar. Beberapa aspek yang perlu diperhatikan untuk membangun karakter anak bangsa adalah aspek agama, budaya dan nilai keilmuan. Namun selama ini nilai-nilai karakter pada segi keilmuan masih terlihat kurang dalam penerapannya (Riva dkk., 2015). Bahan ajar diterapkan dalam pembelajaran IPA di SMP.

Pembelajaran IPA merupakan pembelajaran aktif yang berpusat pada siswa dalam tidak terlepas dari metode ilmiah dalam melakukan pengamatan. Perlu adanya bertanya dalam setiap langkah-langkah metode ilmiah. Pada saat menemukan dan merumuskan masalah, mengumpulkan keterangan/data, memecahkan masalah, menyusun hipotesis, menguji hipotesis, menarik kesimpulan diperlukan bertanya (Irawati, 2015). Tujuan pembelajaran IPA terpadu yaitu meningkatkan efisiensi dan efektivitas pembelajaran, meningkatkan minat dan motivasi, serta beberapa kompetensi dapat dicapai sekaligus. Perlu disadari, bahwa sebenarnya tidak ada model pembelajaran yang cocok untuk semua konsep, oleh karena itu model pembelajaran harus disesuaikan dengan konsep pembelajaran IPA yang akan diajarkan Depdiknas (2006).

Karakteristik pembelajaran IPA terpadu adalah pengalaman belajar secara langsung melalui penggunaan dan pengembangan keterampilan proses dan sikap ilmiah dengan dikembangkan kemampuan berpikir, bekerja, dan bersikap ilmiah serta mengkomunikasikan hasil belajarnya (Kemdiknas, 2011). Menurut Permendikbud Nomor 58 Tahun 2014 Tentang Kurikulum 2013 Sekolah Menengah Pertama/Madrasah Tsanawiyah Kerangka Dasar Dan Struktur Kurikulum SMP/MTs bahwa Ruang Lingkup mata pelajaran IPA di SMP/MTs menekankan pada pengamatan fenomena alam dalam kehidupan sehari-hari yang terkait dengan kompetensi produktif pada konsep abstrak meliputi Biologi, Kimia, Fisika, Bumi dan Alam Semesta. Pembelajaran IPA agar berjalan efektif dalam pelaksanaannya dibutuhkan bahan ajar.

Bahan ajar yang digunakan dalam pembelajaran IPA di jenjang SMP adalah Microsoft Power Point dan Google Form (Mc. Power Point- gg.form). Bahan ajar ini menggunakan software dari windows yaitu Microsoft office yang peruntukkannya untuk presentasi dengan program Microsoft Power Point. Program ini digunakan khusus untuk menyusun bahan ajar yang akan disampaikan dalam bentuk presentasi melalui tayangan slide-slide berurutan sesuai dengan urutan materi pembelajaran IPA. Materi yang akan disampaikan dengan menggunakan program Micosoft Power Point ini adalah materi yang sulit untuk dipahami dengan contoh yang kontekstual sehingga bisa menggunakan ilustrasi pada animasi tayangan pada slide seperti pada Gambar 1.

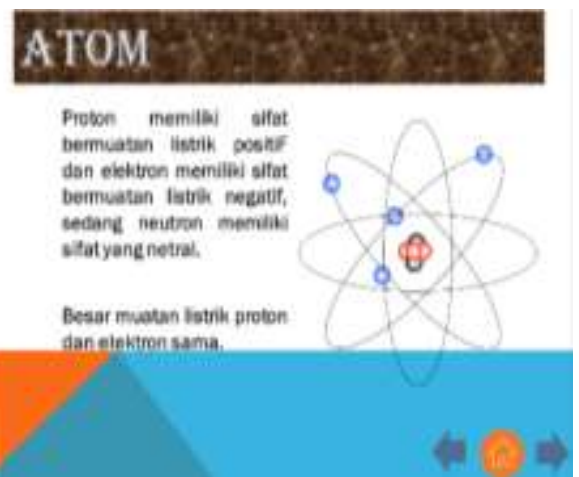

Gambar 1. Media Microsoft Power-point 


\section{Jurnal Pembelajaran Fisika, Vol 9 No 1, Maret 2020, hal 17-25}

Materi yang disampaikan merupakan capaian hasil belajar yang dilakukan oleh guru merupakan tindak mengajar di akhiri dengan proses evaluasi hasil belajar, sedangkan hasil belajar siswa merupakan berakhirnya kegitan yang dilakukan dalam proses belajar (Dimyati dan Mudjiono, 2009) evaluasi hasil belajar ini yang menerapkan software google form untuk memperoleh hasil belajar berupa pre tes dan post tes dengan menggunakan hp android siswa sehingga perolehan capaian hasil belajar sudah bisa terekam oleh gg.form.

Tujuan dari penelitian ini adalah mengkaji validitas bahan ajar Microsoft Power Point dan Google Form (Mc. Power Point- gg.form). Dengan demikian penelitian ini diberi judul validitas bahan ajar Microsoft Power Point dan Google Form (Mc. Power Point- gg.form) untuk Pembelajaran IPA SMP. validitas bahan ajar Microsoft Power Point dan Google Form (Mc. Power Pointgg.form) untuk pembelajaran IPA SMP dirancang untuk mendapatkan bahan ajar yang berbasis siswa. Oleh karena itu, di sekolah pembelajaran IPA sebaiknya menggunakan pembelajaran yang berpusat pada siswa yang diharapkan bisa efektif.

\section{METODE}

Penelitian ini adalah jenis penelitian pengembangan. Menurut Sugiyono (2015) adalah proses meneliti dan mengembangkan kebutuhan pembelajaran dan kemudian mengembangkan produk pendidikan untuk dapat digunakan di sekolah. Produk yang dihasilkan pada penelitian pengembangan ini adalah validitas bahan ajar Microsoft Power Point dan Google Form (Mc. Power Pointgg.form) untuk pembelajaran IPA di SMP. Penelitian pengembangan ini menggunakan model penelitian pengembangan 4-D. Tahap model pengembangan $4-D$ yaitu; 1) Define (Pendefinisian), 2) Design (Perancangan), 3) Develop (Pengembangan) dan 4) Disseminate (Penyebaran) (Thiagarajan et.al., 1974).

Tahap Define (Pendefinisian) adalah tahap mendefinisikan syarat-syarat pembelajaran sesuai dengan kebutuhan pembelajaran IPA. Peneliti melakukan diagnosis awal tentang materi yang sulit diterima siswa dalam kegiatan belajar mengajar karena merupakan materi yang belum bisa ditunjukkan secara kontekstual. Tahap ini dilakukan peneliti adalah untuk mendapatkan gambaran fakta, harapan dan alternatif penyelesaian masalah yang memudahkan dalam penentuan bahan ajar yang akan dikembangkan.

Tahap Design (Perancangan), pada tahap ini diisi dengan kegiatan menyiapkan kerangka konseptual bahan ajar Microsoft Power Point dan Google Form (Mc. Power Point - gg. form) yang disesuaikan dengan aspek penilaian validasi.

a. Validasi Aspek Isi (Materi)

Tabel 1. Indikator dan aspek yang dinilai pada validasi isi (materi)

\begin{tabular}{ll}
\hline Indikator & \multicolumn{1}{c}{ Aspek yang dinilai } \\
\hline \multirow{2}{*}{ Kualitas Materi } & Kidak ada aspek (indikator) yang menyimpang \\
\cline { 2 - 2 } & Kejelasan isi materi (termasuk SK, KD, Indikator) \\
\cline { 2 - 2 } Kraian isi materi \\
\cline { 2 - 2 } Kejelasan contoh yang disertakan \\
\hline Kecakupan contoh yang disertakan \\
\hline Kualitas Soal Latihan & Kejelasan bahasa yang digunakan \\
\hline & Kesesuaian bahasa dengan sasaran pengguna \\
\cline { 2 - 2 } & Keseimbanan latihan/tes dengan kompetensi \\
\hline
\end{tabular}




\section{b. Validasi Pemrograman}

Tabel 2. Indikator dan aspek yang dinilai pada validasi pemrograman

\begin{tabular}{ll}
\hline \multicolumn{1}{c}{ Indikator } & \multicolumn{1}{c}{ Aspek Yang Dinilai } \\
\hline \multirow{3}{*}{ Efisiensi Media } & Kemudahan Pemakaian Program \\
\cline { 2 - 2 } & Kemudahan Memilih Menu Program \\
\cline { 2 - 2 } & Kemudahan Berinteraksi Dengan Program \\
\hline \multirow{2}{*}{ Fungsi Tombol } & Kemudahan Masuk Dan Keluar Dari Program \\
\cline { 2 - 2 } & Kemudahan Memahami Struktur Tombol \\
\hline \multirow{2}{*}{ Kualitas Fisik } & Ketepatan Reaksi Button (Tombol). \\
\cline { 2 - 2 } & Kekuatan/Keawetan Program \\
\hline
\end{tabular}

c. Validasi Tampilan

Tabel 3. Indikator dan aspek yang dinilai pada validasi isi tampilan

\begin{tabular}{ll}
\hline \multicolumn{1}{c}{ Indikator } & \multicolumn{1}{c}{ Aspek yang dinilai } \\
\hline \multirow{4}{*}{ Kualitas Grafis } & Tata Letak Teks dan Gambar \\
\cline { 2 - 2 } & Kesesuaian pemilihan background \\
\cline { 2 - 2 } & Kesesuaian Pemilihan Ukuran dan Jenis Huruf \\
\cline { 2 - 2 } Kesesuaian warna \\
\cline { 2 - 2 } Kemenarikan sajian gambar animasi \\
\cline { 2 - 2 } & Kesesuaian pemilihan gambar animasi dengan materi \\
\cline { 2 - 2 } & Kemenarikan tampilan tombol (button) \\
\hline \multirow{2}{*}{ Keteraturan dan konsistensi tampilan tombol } \\
\hline
\end{tabular}

\section{d. Validasi Respon Pengguna (guru)}

Tabel 4. Indikator dan aspek yang dinilai pada validasi isi (materi)

\begin{tabular}{|c|c|}
\hline Indikator & Aspek Yang Dinilai \\
\hline \multirow{4}{*}{ Aspek Pemrograman } & Kemudahan pemakaian media \\
\hline & Kemudahan memilih menu program \\
\hline & Kemudahan masuk dan keluar dari program \\
\hline & Ketepatan reaksi tombol (button) \\
\hline \multirow{9}{*}{ Aspek Isi } & Kejelasan bahasa yang digunakan \\
\hline & Tidak ada kata/kalimat yang menyimpang \\
\hline & Contoh soal sesuai dengan materi yang disampaikan \\
\hline & Melalui media ini Anda mudah memahami materi pembelajaran \\
\hline & Urutan isi materi sesuai indikator \\
\hline & Contoh-contoh dalam latihan jelas \\
\hline & Bahasa yang digunakan mudah dipahami dan komunikatif \\
\hline & Soal evaluasi (latihan) yang diberikan sesuai dengan kemampuan Anda \\
\hline & $\begin{array}{l}\text { Soal evaluasi yang diberikan/sajikan berurutan sesuai dengan indikator materi } \\
\text { pelajaran }\end{array}$ \\
\hline \multirow{7}{*}{ Aspek Tampilan } & Tata letak teks dan gambar \\
\hline & Kesesuaian pemilihan background \\
\hline & Kesesuaian warna \\
\hline & Kesesuaian pemilihan ukuran dan jenis huruf \\
\hline & Kesesuaian gambar animasi yang disajikan \\
\hline & Kemenarikan tampilan tombol (button) yang digunakan \\
\hline & Kemenarikan gambar animasi yang digunakan \\
\hline
\end{tabular}




\section{Jurnal Pembelajaran Fisika, Vol 9 No 1, Maret 2020, hal 17-25}

Tahap Develop (Pengembangan) dilaksanakan untuk mengetahui validitas bahan ajar Microsoft Power Point dan Google Form (Mc. Power Point- gg.form) untuk pembelajaran IPA di SMP. Validitas bahan ajar Microsoft Power Point dan Google Form (Mc. Power Point- gg.form) didefinisikan sebagai hasil validasi pakar atau ahli bahan ajar. Berdasarkan masukan dari para ahli, materi dan rancangan bahan ajar yang telah disusun direvisi untuk membuat produk lebih tepat, efektif, mudah digunakan, dan memiliki kualitas teknik yang tinggi. Uji lapangan pada produk validitas bahan ajar Microsoft Power Point dan Google Form (Mc. Power Pointgg.form). yaitu pada kelas besar, yaitu pada kelas IX-F tahun ajaran 2019/2020 yang berjumlah 32 peserta didik. Pada saat pelaksaan uji lapangan ini diperoleh penilaian terhadap kepraktisan bahan ajar Microsoft Power Point dan Google Form (Mc. Power Point- gg.form) yang diperoleh dari hasil pengisian angket oleh tiga observer guru. Selain itu, diperoleh data validitas bahan ajar Microsoft Power Point dan Google Form (Mc. Power Point- gg.form) yang dapat dilihat dari indikator validasi bahan ajar.

Data yang diperoleh dari hasil validitas bahan ajar Microsoft Power Point dan Google Form (Mc. Power Point- gg.form) dianalisa dari hasil validasi pada lembar validasi validasi aspek isi (materi), lembar validasi validasi pemrograman, lembar validasi validasi tampilan oleh ahli (dosen) dan validasi pengguna (guru). Data yang diperoleh bersifat deskriptif dan data kuantitatif. Data deskriptif berasal dari saran dan komentar dari validator. Data kuantitatif berasal dari penilaian aspek penilaian menggunakan check-list $(\sqrt{ })$ dengan kriteria sebagai berikut.

Skor 4, apabila validator memberikan penilaian sangat baik.

Skor 3, apabila validator memberikan penilaian baik.

Skor 2, apabila validator memberikan penilaian kurang baik.

Skor 1, apabila validator memberikan penilaian tidak baik.
Data yang diperoleh dari hasil validasi akan dianalisis menggunakan teknik analisa data persentase.

Keterangan :

$$
\mathrm{V}=\frac{\mathrm{T}_{\mathrm{SE}}}{\mathrm{T}_{\mathrm{SM}}} \times 100 \%
$$

$\mathrm{V}=$ persentase tingkat penilaian

$\mathrm{T}_{\mathrm{SE}} \quad=$ total skor empirik yang diperoleh

$\mathrm{T}_{\mathrm{SM}} \quad=$ total skor maksimum

(Akbar, 2013)

Data persentase yang diperoleh dengan menggunakan rumus di atas diubah menjadi data kulitatif deskriptif dengan menggunakan kriteria penilaian validasi dan bahan ajar Microsoft Power Point dan Google Form (Mc. Power Point- gg.form) untuk pembelajaran IPA di SMP sebagai berikut.

Tabel. 5 Kriteria Validasi dan Kepraktisan

\begin{tabular}{cll}
\hline $\begin{array}{c}\text { Persentase } \\
(\%)\end{array}$ & Kategori & \multicolumn{1}{c}{ Keputusan } \\
\hline $81,25-$ & $\begin{array}{l}\text { Sangat } \\
\text { Valid }\end{array}$ & $\begin{array}{l}\text { Produk siap dimanfaatkan } \\
\text { dilapangan sebenarnya untuk } \\
\text { kegiatan pembelajaran }\end{array}$ \\
\hline & & $\begin{array}{l}\text { Produk dapat dilanjutkan } \\
\text { dengan menambahkan sesuatu } \\
\text { yang kurang, melakukan } \\
\text { pertimbangan-pertimbangan } \\
\text { tertentu, penambahan yang } \\
\text { dilakukan tidak terlalu besar, } \\
\text { dan tidak mendasar. }\end{array}$ \\
$62,5-$ & Valid & $\begin{array}{l}\text { Merevisi dengan meneliti } \\
\text { kembali secara seksama dan } \\
\text { mencari kelemahan- } \\
\text { kelemahan produk untuk } \\
\text { disempurnakan }\end{array}$ \\
& & $\begin{array}{l}\text { Merevisi secara besar-besaran } \\
\text { dan mendasar tentang isi } \\
\text { produk }\end{array}$ \\
\hline $43,75-$ & Kurang & Valid \\
& Tidak & Valid
\end{tabular}

(Akbar, 2013)

Jika dari hasil validas diperoleh kriteria rendah maka dilakukan revisi terhadap produk bahan ajar Microsoft Power Point dan Google Form (Mc. Power Point- gg.form) perlu dikembangkan lebih baik lagi.

Tahap Disseminate (Penyebaran) merupakan tahap akhir pengembangan produk dengan mencetak buku panduan bahan ajar Microsoft Power Point dan Google Form (Mc. Power Point- gg.form) disebarluaskan supaya dapat diserap (diffusi) orang lain untuk digunakan (diadopsi) pada pembelajaran IPA, dalam penelitian ini buku dikenalkan ke MGMP IPA Kabupaten Probolinggo. 


\section{HASIL DAN PEMBAHASAN}

Data validitas bahan ajar Microsoft Power Point dan Google Form (Mc. Pointgg.form) dapat dilihat dari hasil penilaian validasi dua pakar ahli dan pengguna (guru) pada pembelajaran IPA. Penilaian validitas materi pada bahan ajar Microsoft Power Point dan Google Form (Mc. Point-gg.form) yang dilaksanakan oleh pakar (ahli) dapat dilihat pada Tabel 6.

Data Tabel 6 menunjukkan bahwa rerata hasil validasi bahan ajar Microsoft Power Point dan Google Form (Mc. Point-gg.form) pada aspek Kualitas Materi yaitu 90\%, pada aspek Kualitas Bahasan yaitu $85 \%$, pada aspek Kualitas Soal Latihan yaitu 86,77\%.

Rerata hasil validasi materi pada bahan ajar Microsoft Power Point dan Google Form (Mc. Point-gg.form) secara keseluruhan $87,26 \%$ dengan kategori sangat valid sehingga bahan ajar Microsoft Power Point dan Google Form (Mc. Point-gg.form) dapat digunakan. Penilaian validitas pemrograman pada bahan ajar Microsoft Power Point dan Google Form (Mc. Point-gg.form) yang dilaksanakan oleh pakar (ahli) dapat dilihat pada Tabel 7.

Tabel. 6 Hasil Validasi Aspek Isi (Materi)

\begin{tabular}{|c|c|c|c|}
\hline \multirow{2}{*}{ Indikator } & \multirow{2}{*}{ Aspek yang dinilai } & \multicolumn{2}{|c|}{ Penilaian Validator } \\
\hline & & 1 & 2 \\
\hline \multirow{10}{*}{ Kualitas Materi } & Tidak ada aspek (indikator) yang menyimpang & 5 & 5 \\
\hline & Keluasan cakupan isi materi & 4 & 5 \\
\hline & Kejelasan isi materi (termasuk SK, KD, Indikator) & 5 & 4 \\
\hline & Uraian isi materi & 5 & 4 \\
\hline & Kejelasan contoh yang disertakan & 4 & 4 \\
\hline & Kecakupan contoh yang disertakan & 4 & 5 \\
\hline & Jumlah Validasi & 27 & 27 \\
\hline & Persentase Validasi & $90 \%$ & $90 \%$ \\
\hline & Rata-rata Persentase Validasi & \multicolumn{2}{|c|}{$90 \%$} \\
\hline & Kategori Rata-rata Persentase Validasi & \multicolumn{2}{|c|}{ Sangat Valid } \\
\hline \multirow{7}{*}{$\begin{array}{l}\text { Kualitas } \\
\text { Bahasan }\end{array}$} & Kejelasan bahasa yang digunakan & 4 & 4 \\
\hline & Kesesuaian bahasa dengan sasaran pengguna & 4 & 5 \\
\hline & Jumlah Validasi & 8 & 9 \\
\hline & Persentase Validasi & $80 \%$ & $90 \%$ \\
\hline & Rata-rata Persentase Validasi & \multicolumn{2}{|c|}{$85 \%$} \\
\hline & Kategori Rata-rata Persentase Validasi & \multicolumn{2}{|c|}{ Sangat Valid } \\
\hline & Kesesuaian latihan/tes dengan kompetensi & 4 & 5 \\
\hline \multirow[t]{6}{*}{$\begin{array}{l}\text { Kualitas Soal } \\
\text { Latihan }\end{array}$} & $\begin{array}{l}\begin{array}{l}\text { Keseimbangan soal latihan/tes evaluasi dengan } \\
\text { materi }\end{array} \\
\end{array}$ & 5 & 4 \\
\hline & Runtutan soal evaluasi yang disajikan & 4 & 4 \\
\hline & $\underline{\text { Jumlah Validasi }}$ & 13 & 13 \\
\hline & Persentase Validasi & $86.77 \%$ & $86,77 \%$ \\
\hline & Rata-rata Persentase Validasi & \multicolumn{2}{|c|}{$86,77 \%$} \\
\hline & Kategori Rata-rata Persentase Validasi & \multicolumn{2}{|c|}{ Sangat Valid } \\
\hline \multicolumn{2}{|c|}{ Jumlah Rata-Rata Total } & \multicolumn{2}{|c|}{$261,77 \%$} \\
\hline \multicolumn{2}{|c|}{ Rata-Rata Persentase Total } & \multicolumn{2}{|c|}{$87,26 \%$} \\
\hline \multicolumn{2}{|l|}{ Kategori } & \multicolumn{2}{|c|}{ Sangat Valid } \\
\hline
\end{tabular}


Tabel. 7 Hasil Validasi Pemrograman

\begin{tabular}{|c|c|c|c|}
\hline \multirow{2}{*}{ Indikator } & \multirow{2}{*}{ Aspek Yang Dinilai } & \multicolumn{2}{|c|}{ Validator } \\
\hline & & 1 & 2 \\
\hline \multirow[t]{8}{*}{ Efisiensi Media } & Kemudahan Pemakaian Program & 4 & 5 \\
\hline & Kemudahan Memilih Menu Program & 5 & 4 \\
\hline & Kemudahan Berinteraksi Dengan Program & 4 & 4 \\
\hline & Kemudahan Masuk Dan Keluar Dari Program & 4 & 4 \\
\hline & Jumlah Validasi & 17 & 17 \\
\hline & Persentase Validasi & $85 \%$ & $85 \%$ \\
\hline & Rata-Rata Persentase Validasi & \multicolumn{2}{|c|}{$85 \%$} \\
\hline & Kategori Rata-Rata Persentase Validasi & \multicolumn{2}{|c|}{ Sangat Valid } \\
\hline \multirow{6}{*}{ Fungsi Tombol } & Kemudahan Memahami Struktur Tombol & 4 & 4 \\
\hline & Ketepatan Reaksi Button (Tombol). & 4 & 4 \\
\hline & Jumlah Validasi & 16 & 16 \\
\hline & Persentase Validasi & $80 \%$ & $80 \%$ \\
\hline & Rata-Rata Persentase Validasi & \multicolumn{2}{|c|}{$80 \%$} \\
\hline & Kategori Rata-Rata Persentase Validasi & \multicolumn{2}{|c|}{ Valid } \\
\hline \multirow[t]{6}{*}{ Kualitas Fisik } & $\begin{array}{l}\text { Kapasitas File Program Untuk Kemudahan } \\
\text { Duplikasi/Penggandaan }\end{array}$ & 5 & 5 \\
\hline & Kekuatan/Keawetan Program & 5 & 5 \\
\hline & Jumlah Validasi & 10 & 10 \\
\hline & Persentase Validasi & $100 \%$ & $100 \%$ \\
\hline & Rata-Rata Persentase Validasi & \multicolumn{2}{|c|}{$100 \%$} \\
\hline & Kategori Rata-Rata Persentase Validasi & \multicolumn{2}{|c|}{ Sangat Valid } \\
\hline \multicolumn{2}{|c|}{ Jumlah Rata-Rata Total } & \multicolumn{2}{|c|}{265} \\
\hline \multicolumn{2}{|c|}{ Rata-Rata Persentase Total } & $88,33 \%$ & t Valid) \\
\hline
\end{tabular}

Data Tabel 7 menunjukkan bahwa rerata hasil validasi pemrograman pada bahan ajar Microsoft Power Point dan Google Form (Mc. Point-gg.form) pada aspek Efisiensi Media 85\%, aspek Fungsi Tombol 80\%, aspek Kualitas Fisik 100\%.

Rerata hasil validasi pemrograman pada bahan ajar Microsoft Power Point dan Google Form (Mc. Point-gg.form) secara keseluruhan 88,33 \% dengan kategori sangat valid sehingga bahan ajar Microsoft Power Point dan Google Form ( Mc. Pointgg.form) dapat digunakan. Penilaian validitas tampilan pada bahan ajar Microsoft Power Point dan Google Form (Mc. Point-gg.form) yang dilaksanakan oleh pakar (ahli) dapat dilihat pada Tabel 8.

Tabel 8. Hasil Validasi Tampilan

\begin{tabular}{|c|c|c|c|}
\hline \multirow{2}{*}{ Indikator } & \multirow{2}{*}{ Aspek yang dinilai } & \multicolumn{2}{|c|}{ Validator } \\
\hline & & 1 & 2 \\
\hline \multirow{10}{*}{ Kualitas Grafis } & Tata Letak Teks dan Gambar & 5 & 5 \\
\hline & Kesesuaian pemilihan background & 4 & 4 \\
\hline & Kesesuaian Pemilihan Ukuran dan Jenis Huruf & 4 & 4 \\
\hline & Kesesuaian warna & 4 & 4 \\
\hline & Kemenarikan sajian gambar animasi & 4 & 4 \\
\hline & Kesesuaian pemilihan gambar animasi dengan materi & 5 & 4 \\
\hline & Jumlah validasi & 26 & 25 \\
\hline & Persentase validasi & $86,77 \%$ & $83,33 \%$ \\
\hline & Rata-rata persentase validasi & \multicolumn{2}{|c|}{$85,05 \%$} \\
\hline & Kategori rata-rata persentase validasi & \multicolumn{2}{|c|}{ Sangat Valid } \\
\hline \multirow[t]{6}{*}{ Kualitas Tombol } & Kemenarikan tampilan tombol (button) & 5 & 5 \\
\hline & Keteraturan dan konsistensi tampilan tombol & 5 & 4 \\
\hline & Jumlah validasi & 10 & 9 \\
\hline & Persentase validasi & $100 \%$ & $90 \%$ \\
\hline & Rata-rata persentase validasi & \multicolumn{2}{|c|}{$95 \%$} \\
\hline & Kategori rata-rata persentase validasi & \multicolumn{2}{|c|}{ Sangat Valid } \\
\hline \multicolumn{2}{|c|}{ Jumlah Rata-Rata Total } & \multicolumn{2}{|c|}{180,05} \\
\hline \multicolumn{2}{|c|}{ Rata-Rata Persentase Total } & \multicolumn{2}{|c|}{$90,03 \%$ (Sangat Valid) } \\
\hline
\end{tabular}


Data Tabel 8 menunjukkan bahwa rerata hasil validasi tampilan bahan ajar Microsoft Power Point dan Google Form (Mc. Point-gg.form) pada aspek Kualitas Grafis 85,05\% dan aspek Kualitas Tombol $95 \%$.

Rerata hasil validasi tampilan pada bahan ajar Microsoft Power Point dan Google Form (Mc. Point-gg.form) secara keseluruhan 90,03 \% dengan kategori sangat valid sehingga bahan ajar Microsoft Power Point dan Google Form (Mc. Pointgg.form) dapat digunakan. Penilaian validitas pemrograman pada bahan ajar Microsoft Power Point dan Google Form ( Mc. Point-gg. form) yang dilaksanakan oleh pengguna (guru) dapat dilihat pada Tabel 9.

Tabel 9. Hasil Validasi Respon Pengguna (Guru)

\begin{tabular}{|c|c|c|c|c|}
\hline \multirow{3}{*}{ Indikator } & \multirow{3}{*}{ Aspek Yang Dinilai } & \multirow{2}{*}{\multicolumn{3}{|c|}{$\begin{array}{c}\text { Validator } \\
\text { Pengguna (Guru) }\end{array}$}} \\
\hline & & & & \\
\hline & & 1 & 2 & 3 \\
\hline \multirow{8}{*}{$\begin{array}{c}\text { Aspek } \\
\text { Pemrograman }\end{array}$} & Kemudahan pemakaian media & 4 & 4 & 4 \\
\hline & Kemudahan memilih menu program & 3 & 4 & 4 \\
\hline & Kemudahan masuk dan keluar dari program & 4 & 4 & 4 \\
\hline & Ketepatan reaksi tombol (button) & 4 & 4 & 4 \\
\hline & Jumlah Validasi & 15 & 16 & 16 \\
\hline & Persentase Validasi & 75 & 80 & 80 \\
\hline & Rata-rata Persentase Validasi & \multicolumn{3}{|c|}{$78 \%$} \\
\hline & Kategori Rata-rata Persentase Validasi & \multicolumn{3}{|c|}{ Valid. } \\
\hline \multirow{13}{*}{ Aspek Isi } & Kejelasan bahasa yang digunakan & 3 & 5 & 4 \\
\hline & Tidak ada kata/kalimat yang menyimpang & 5 & 5 & 4 \\
\hline & Contoh soal sesuai dengan materi yang disampaikan & 4 & 5 & 5 \\
\hline & $\begin{array}{l}\begin{array}{l}\text { Melalui media ini Anda mudah memahami materi } \\
\text { pembelajaran }\end{array} \\
\end{array}$ & 2 & 5 & 5 \\
\hline & Urutan isi materi sesuai indikator & 4 & 5 & 4 \\
\hline & Contoh-contoh dalam latihan jelas & 3 & 4 & 4 \\
\hline & Bahasa yang digunakan mudah dipahami dan komunikatif & 5 & 5 & 5 \\
\hline & $\begin{array}{l}\text { Soal evaluasi (latihan) yang diberikan sesuai dengan } \\
\text { kemampuan Anda }\end{array}$ & 4 & 5 & 4 \\
\hline & $\begin{array}{l}\text { Soal evaluasi yang diberikan/sajikan berurutan sesuai } \\
\text { dengan indikator materi pelajaran }\end{array}$ & 4 & 5 & 4 \\
\hline & Jumlah Validasi & 34 & 44 & 39 \\
\hline & Persentase Validasi & 76 & 98 & 87 \\
\hline & Rata-rata Persentase Validasi & \multicolumn{3}{|c|}{$87 \%$} \\
\hline & Kategori Rata-rata Persentase Validasi & \multicolumn{3}{|c|}{ Sangat Valid } \\
\hline \multirow{13}{*}{ Aspek Tampilan } & Tata letak teks dan gambar & 4 & 4 & 4 \\
\hline & Kesesuaian pemilihan background & 4 & 5 & 4 \\
\hline & Kesesuaian warna & 3 & 4 & 4 \\
\hline & Kesesuaian pemilihan ukuran dan jenis huruf & 3 & 4 & 4 \\
\hline & Kesesuaian gambar animasi yang disajikan & 3 & 5 & 4 \\
\hline & Kemenarikan tampilan tombol (button) yang digunakan & 3 & 5 & 4 \\
\hline & Kemenarikan gambar animasi yang digunakan & 4 & 5 & 4 \\
\hline & Jumlah Validasi & 24 & 32 & 28 \\
\hline & Persentase Validasi & 69 & 91 & 80 \\
\hline & Rata-rata Persentase Validasi & \multicolumn{3}{|c|}{$80 \%$} \\
\hline & Kategori Rata-rata Persentase Validasi & \multicolumn{3}{|c|}{ Sangat Valid } \\
\hline & Jumlah Rata-Rata Total & \multicolumn{3}{|c|}{245} \\
\hline & Rata-Rata Persentase Total & \multicolumn{3}{|c|}{$82 \%$ (Sangat Valid) } \\
\hline
\end{tabular}


Data Tabel 9 menunjukkan bahwa rerata hasil validasi respon pengguna (guru) bahan ajar Microsoft Power Point dan Google Form (Mc. Point-gg.form) pada aspek Aspek Pemrograman $78 \%$ dan aspek isi $87 \%$ dan aspek tampilan $80 \%$. Rerata hasil validasi respon pengguna (guru) pada bahan ajar Microsoft Power Point dan Google Form (Mc. Point-gg.form) secara keseluruhan $82 \%$ dengan kategori sangat valid sehingga bahan ajar Microsoft Power Point dan Google Form (Mc. Pointgg.form) dapat digunakan.

\section{KESIMPULAN}

Berdasarkan data yang diperoleh pada hasil dan pembahasan validitas bahan ajar Microsoft Power Point dan Google Form (Mc. Point-gg.form) untuk pembelajaran IPA di SMP yang telah diuraikan, maka kesimpulannya bahwa validitas bahan ajar Microsoft Power Point dan Google Form (Mc. Point-gg.form) dapat dilihat dari hasil validasi berupa penilaian dari dua pakar ahli dan penilaian dari respon pengguna (guru). Sehingga diperoleh bahan ajar Microsoft Power Point dan Google Form (Mc. Point-gg.form) yang valid untuk pembelajaran IPA di SMP.

\section{UCAPAN TERIMA KASIH}

1. Dra. Anda Baroroh. selaku Kepala SMP Negeri 1 Dringu yang telah membantu memberikan dukungan terhadap penulisan artikel ini.

2. Ganif Rojikin, S.Pd, M.M selaku Validator 1 dan pengawas Dikdasmen pada Dinas Pendidikan Kabupaten Probolinggo.

3. Drs. Sunarto, M.Pd selaku validator 2 dan wakil kepala SMP Negeri 1 Dringu;

5. Titin Sumartini, M.Pd, Sugeng Rahmono, S.Pd, Hayati, S.Pd selaku validator Respon Pengguna (guru) dan guru di wilayah Dinas Pendidikan Kabupaten Probolinggo.

\section{DAFTAR PUSTAKA}

Akbar, S. 2013. Instrumen Perangkat Pembelajaran. Bandung: Remaja Rosdakarya.
Anwar, Rusliansyah. 2014. Hal-hal yang mendasari penerapan kurikulum 2013. Humaniora, 5(1), 97-106

Depdiknas. 2006. Panduan Pengembangan Bahan Ajar IPA. Jakarta: Dirjen Pendidikan Dasar dan menengah. Direktorat PSMP.

Dimiyati dan Mudjiono. 2009. Belajar dan Pembelajaran. Jakarta: Rineka Cipta.

Irawati, R. 2015. Gambaran Pengenalan Model Pembelajaran QODE (Questioning, Organizing, Doing and Evaluating) Pada Guru IPA SMP di Kabupaten Probolinggo. Surabaya: Prosiding Seminar Nasional Jurusan Fisika FMIPA-UNESA

Kemdiknas. 2011. Panduan Pengembangan Pembelajaran IPA Secara Terpadu. Jakarta: Direktorat Sekolah Menengah Pertama.

Lestari, I. 2013. Pengembangan Bahan Ajar Berbasis Kompetensi: Sesuai dengan Kurikulum Tingkat Satuan Pendidikan. Padang: Akademia Permata.

P21. 2014. Learning for The 21st Century: A Report and MILE Guide for $21^{\text {st }}$ Century Skills. Retrived from (http://www.21centuryskills.org) on 13 Oktober 2017

Riva, S., Darvina, Y., dan Masril. 2015. Pengaruh Penerapan Ajar Berbasis Karakter Melalui Model Pembelajaran POE Terhadap Hasil Belajar Siswa Kelas XI SMAN 5 Padang. Pillar of Physics Education. 5(113-120).

Sugiyono, 2011. Metode Penelitian Pendidikan Pendekatan Kuantitatif, Kualitatif, dan $R \& D$. Bandung: Alfabeta.

Thiagarajan, S., Semmel, D.S., \& Semmel, M.I. 1974. Instructional Development for Training Teachers of Exceptional Children. Minnesota. Leadership Training Institute/Special Education, University of Minnesota, Minneapolis.

Virani, W. S., Supeno, Supriadi, B. 2018. Kajian kinematika gerak pada jalur lokasi kecelakaan berisiko tinggi (blackspot) sebagai sumber belajar fisika di SMA. Jurnal Riset dan Kajian Pendidikan Fisika, 5(1), 22-29. 